\title{
Dystopian Schools: Recovering Dewey's Radical Aesthetics in an Age of Utopia- Gone-Wrong
}

\section{Jessica A. Heybach and Eric C. Sheffield}

While utopians cannot produce what they can imagine, we can no longer imagine what we produce.

- Günther Anders

\section{Abstract}

In this article, we first suggest that contemporary school policies and practices represent a utopia-gone-wrong. In striving for an unattainable educational utopia - that is, all students will be proficient in math and reading by 2014 - current polices and their resulting practices have brought a classic dystopian turn - the dehumanization of students, teachers, and administrators. We then argue that such a turn can best be seen and then potentially stopped via a complete dystopian theory of education grounded in John Dewey's radical aesthetics. In utilizing Dewey's aesthetic theory as a lens of analysis, we argue that this turn toward dystopia is resulting in an increasingly numbing, anaesthetic educational experience at best; and a dehumanizing, violent educational experience at worst. Finally, we briefly ponder an antidote for our dystopian malaise: human love.

\section{Introduction: A Dystopian Aesthetic Vignette}

It is increasingly the case that undergraduate teacher candidates find themselves enrolled in courses that have been developed "in partnership" with local school districts - districts adjacent to the actual universities where they are enrolled. Recently, one such partnership arrangement had a foundation of education professor and initial certification students oscillating between two school districts located in the same large suburban area. One side of town is inhabited by mostly minority children in underfunded schools - commonly viewed as the "bad" district. The other side of town has the "better" district, as it is the home of better school funding mechanisms, and many beautiful newly built school buildings; the particular school discussed below opened its doors less than a decade ago. This district also has the addition of newer middle and upper middle class families in luxury 
suburban homes; such disparity in the midst of geographical proximity is, of course, nothing new. However, both districts have felt the devastating effects of violence, drugs, bullying, and an over-active police presence-in the grand scheme of suburban expectations, neither of these districts represents the first choice for parents desperate to provide an idyllic, utopian schooling experience for their children.

As this professor sat teaching class one afternoon (in the better of the two districts described above), half of the students (who were completing a lunchroom observation) arrived back in class aghast at what they had just experienced. They all began talking at once, describing a rant they had witnessed by the Dean of Students to sixth graders: "I am prepared to take you down;" "We are tired of this crap;" "I will tackle you if I have to!" The undergraduate teacher candidates reported that the sixth graders had sat in silence listening to the Dean's tirade about the previous day's trouble between a small group of "black and Mexican" students while they, the soon-to-be teachers, looked on in awkward silence. The undergraduates reported feeling disbelief at what they had heard - many of them clearly troubled if not completely distraught. Within minutes of their return, the ranting Dean entered the "partnership" classroom and asked for class time to provide some context for what the pre-service teachers had just witnessed. Instead of explaining this context, the Dean proceeded to defend what was said, repeating a willingness to use mightagainst-might, threatening to have any student arrested who did not comply with school policies, espousing a strong relationship between the school and the police department, and so on. Following the Dean's comments, one of the undergraduates raised his hand and asked, "We are reading John Dewey and learning about his notion of experience ... what do you think about those ideas?" The Dean quickly replied, "Yeah, that's all good in theory." The obvious corollary is that in practice those ideas are all but dead-especially so given how youth today are seemingly different from previous generations of compliant and respectful youth.

In the week leading up to this unintended experience-now a collateral learning experience in the Deweyan sense-these pre-service teachers had read Experience and Education, and watched parts of the documentary film, The War on Kids. ${ }^{2}$ They had discussed Dewey's ideas about experience, purpose, social control, continuity, and the give and take between traditional and progressive forms of education and classroom organization. They had debated what Dewey meant by democracy, and whether schools could or should be a site in which to expand the project of democracy. In an all-too-perfect interruption to the images of children being subjected to police dogs and officers with weapons drawn in a South Carolina school drug raid in the film The War on Kids, a school-wide announcement came over the loud speakers: "Excuse the interruption teachers, we need all faculty and staff to stand and search students for a missing walkie-talkie that was taken from the gym." The students and professor alike stared at each other in momentary silence, and before the class could begin again, a voice reemerged on the 
speakers, "And whoever is found to be in possession of the missing walkie-talkie will be immediately arrested by Officer ." The class erupted in an awkward laughter and the pre-service students asked, "Did you plan this?" The professor sarcastically responded, "Yep, I stole the walkie-talkie to prove a point about school policy." Of course, none of this is in fact funny (and the professor had obviously not actually stolen the walkie-talkie) - but, might both the students and professor imagine for a moment what it must be like to be 11,12 , and 13 years of age in this kind of environment?

To be fair, we tell this story not to bash the local administrators, or to offer up the Dean as a jester in the court of academia. The Dean was clearly shaken by the events, and in public conversations since, he has repeated to both the professor and the teacher candidates, "I don't know what to do anymore. I spend my days reading and searching for an answer about what to do with all these problems." Following that dystopian day, the teacher candidates came to empathize with the Dean, but they remained skeptical of the apparent conclusion that there are no better means available to reach at-risk youth. One student even jokingly invited the Dean to "read this little book Dewey wrote." The professor reported being shocked at how committed the pre-service teacher candidates became to what Dewey had offered them, and the skepticism they retained as they witnessed the construction (and deconstruction) of youth in the school. Many of these students were deeply bothered by these experiences, and they openly wondered whether these young students in fact needed to be saved from themselves through oppressive dictatorial administrative actions-actions that can only be described as dystopian-the epitome of a Deweyan anaesthetic, miseducative experience.

As an object of critical analysis, we believe that the use of dystopia to investigate the current state of education conjures up the telltale signs usually associated with imaginary dystopian places: oppression, terror, deprivation, surveillance, dehumanization, punitive discipline, state sponsored violence, and many more characteristics to be highlighted later. However, we hesitate, and caution our reader that our critique of schooling through a dystopian lens does not assume that contemporary school policy and practice have yet created a totalizing overt system of surveillance and control, as is the case, for example, in George Orwell's Oceania. On the other hand, education is a powerful tool (think Hitler's Germany, Stalin's Soviet Union, or even the film Jesus Camp), and dystopian themes and practices constitute the slipperiest of slopes. ${ }^{3}$ Might it be that it is the covert institutional destruction of self, rather than the overt version found in 1984, which is most difficult to locate and resist?

For those of us who find that the work of John Dewey continues to provide important insights (even in the face of Dewey fatigue), we certainly must question whether he-the epitome of the modern thinker-can have anything much to say to us "postmoderns" in regards to a dystopian critique of contemporary schooling. 
We believe Dewey continues to speak to us in indispensable ways, especially so in his theorizing about imaginary utopian schools, and in a recovery of his radicalized aesthetics that help us begin to see our dystopian malaise and its influence on our socially constructed schooling experiences. First, we will revisit Dewey's 1933 article where he outlines what he believes to be a utopian vision for schools; and then, we utilize Dewey's aesthetic theory, in tandem with his theory of experience, to reveal what has become of our current utopian plans for schooling in America. Before concluding with some thoughts as to why a dystopian theory is potentially so important, we revisit the classic dystopian antidote: human love.

\section{DEWEY's UTOPIAN Vision}

Dewey opens his 1933 New York Times op-ed with the statement: "The most Utopian thing in Utopia is that there are no schools at all" (our emphasis). ${ }^{4}$ The utopian move to eliminate schools and create a society without schools seems silly even for the most imaginative among us. Is such a reality even conceivable in today's context? How would youth learn the necessary skills to become productive adults who could contribute to economic imperatives of the times without schooling? How can children be properly educated and shaped without a systematic and organized delivery of curriculum? We ask these questions in jest, as rhetorical fodder, knowing that these ideas offer a counternarrative of impossibility (a society without schools?). Yet, Dewey's opening salvo can be thought of as the impetus for its inverse: is the most dystopian thing in Dystopia the institution of schooling? Are schools, in fact, the core mechanism by which Dystopia is achieved? Are the usual systemic suspects of surveillance, fear, loss of autonomy and violence not nearly as disturbing as the vision that children must be "schooled?" To begin this discussion, we want to outline Dewey's theorizing about utopian schools and then for contrast, move towards a dystopian theory of schools.

Dewey begins his description of schools with an examination of how relationships are formed as a central feature of the schools that he encounters in Utopia: "close, intimate personal acquaintance on the part of people who associate together."5 Learning by and through associations with others becomes a vital, a priori, understanding in Utopia. As many adults and children know, today's schooling structures and practices often result in a detached, impersonal experience that lacks deep personal associations with others. Moreover, the school has become a place that often exaggerates the felt experience of student isolation, loneliness, inadequacy, and indifference. Whereas Dewey's utopian school fosters meaningful, often loving relationships by design to achieve the aims of Utopia, contemporary dystopian schooling realities should be seen as by design as well, and thus, could be un-designed.

As Dewey continues his visit to Utopia, he includes a description of the "assembly places" where children of all ages would meet. He describes utopian "assembly places" as similar to "our present open-air schools in their physical struc- 
ture ... [but] none of the things we usually associate with our present schools." Similarly, the school in the opening vignette was architecturally designed in the spirit of this utopian ideal of physical space. Each classroom has a double-wide glass garage door that could be opened up to create a large common area among multiple classrooms. Today, these doors have been covered up with student work and instructional posters so that students cannot see out of the classroom-minimizing the potential for distractions and moments for the mind to wander out the "window" while optimizing the amount of content that can be delivered to students. These doors, once meant to stimulate freedom of movement, are now padlocked so that they may not be opened. Although these locks may not be a permanent reality-they could be unlocked-the padlock is sadly symbolic of what appears to have been lost in recent years as the pressure for standardization and corporate models of accountability have increased in American schooling.

Another aspect of Dewey's description of utopian schools is an educational experience where children of various ages can engage in learning together, some novices, some experts, but all together participating in simultaneous co-learning-in relationships. Conversely, today, we find rigid configurations that sequester children by age and ability into particular groups destined for particular ends. In the case of middle schools, often there is the practice of segregating all student movement by grade level. Thus, 6 th graders would never be seen eating lunch nor occupying the same passing period as 8th graders. All interactions have been arranged and managed, with parental and societal consent, by the adults in the building, so as to limit children's ability to influence each other physically in the assumed negative ways. As a result, students are routinely "batched" into a system that makes gross assumptions regarding the uniformity of human and academic development, thus resulting in the unintended consequence of children rarely learning the necessary capacity needed to relate to difference. Although this practice may be grounded in individual psychological imperatives of adolescent development, philosophically speaking, it is reflective of something entirely different.

Dewey prophetically critiques the state of schooling today and what appears to be a persistent, if not neurotic, attachment to the belief that learning objectives must be incremental, linear, and can be prescribed by others far removed from the activity of learning. Dewey writes,

Naturally I inquired what were the purposes, or, as we say now, the objectives, of the activities carried on in these centres. At first nothing puzzled me more than the fact that my inquiry after objectives was not at all understood, for the whole concept of the school, of teachers and pupils and lessons, had so completely disappeared that when I asked after the special objectives of the activity of these centres, my Utopian friends thought I was asking why children should live at all, and therefore they did not take my questions seriously. 
After I made them understand what I meant, my question was dismissed with the remark that since children were alive and growing, "of course, we, as Utopians, try to make their lives worthwhile to them; of course, we try to see that they really do grow, that they really develop." But as for having any objective beyond the process of a developing life, the idea still seemed to them quite silly. The notion that there was some special end which the young should try to attain was completely foreign to their thoughts.

If in Utopia there are no prescribed objectives beyond living, then it seems in Dystopia there are only objectives to direct all human activity, educationally or otherwise. The obvious manifestations of "only objectives" can be seen in the Common Core Standards, edTPA, and the persistent attachment of standards to every piece of student work that adorns the hallways of most schools in America. ${ }^{8}$ Gone are the days when student work was hung to honor their accomplishments unmediated by an official state and/or national code and description (e.g., CCSS.ELA-Literacy.RL.6.3: Describe how a particular story's or drama's plot unfolds in a series of episodes as well as how the characters respond or change as the plot moves toward a resolution).

Another hallmark of Utopia is a belief in the inevitability of learning-literally the belief that there is no way not to learn what is needed to grow into an adult. Dewey writes, "I inquired ... how with their [the Utopians] methods they ever made sure that the children and youth really learned anything, how they mastered the subject matter, geography and arithmetic and history, and how they ever were sure that they really learned to read and write and figure." ${ }^{9}$ Here again, we see today's collective consciousness, a common sense of instruction-hysteria reflected back at us. The Utopians respond, quite comically, with, "was [it] true that in our day we had to have schools and teachers and examinations to make sure that babies learned to walk and to talk."10 Of course, not withstanding a developmental delay or special need, this statement should expose how bizarre educators' and society's attachment to "instruction" has become, let alone the belief that all will achieve in lock-step at the same time. Still, there seems to be the issue of control at the core which distinguishes Utopia from Dystopia-the Utopian seeks not to control others, while the Dystopian seeks only to control others-to (it seems) save them from themselves.

Returning to the discussion of the aims of education, the Utopians illustrate for Dewey their belief that our schooling has become solely a function of our economic reality, which is predicated on personal acquisition and private possession. The Utopians in Dewey's article argue that we "had come to regard all study as simply a method of acquiring something, even if only useless or remote facts, and thought of learning and scholarship as the private possession of the resulting acquisition." 11 This logic certainly finds various and persistent expressions in today's contemporary schooling experiences. Conversely, Dewey illustrates the utopian logic regarding possession and acquisition: 
Great educational liberation came about when the concept of external attainments was thrown away and when they started to find out what each individual person had in him from the very beginning, and then devoted themselves to finding out the conditions of the environment and the kinds of activity in which the positive capacities of each young person could operate most effectually. ${ }^{12}$

The statement, "they started to find out what each individual person had in him from the very beginning" is reminiscent of the etymology of the term "education"-from the Latin educare: "to draw forth from within." Such a statement should remind teachers that much of what makes our schooling experience emblematic of Dystopia is its unrelenting adherence to externally imposed "banking" forms of instruction that are the cornerstone of schooling in American society. ${ }^{13}$ Such practices have no place in Dewey's conception of the utopian school.

Finally, Dewey concludes his description by noting that in Utopia the young achieve a sense of "positive power"-what we take to be a sense of agency and competency in society. This attitude could only be created through a preoccupation with the "all-around development of the capacities of the young." In particular, Dewey's vision demands the creation of experiences that eliminate fear, embarrassment, constraint, self-consciousness, failure, and incapacity. ${ }^{14}$ Even a cursory survey of schooling in America and most will find, in many places, policy seemingly dedicated to the achievement of "fear, embarrassment, constraint, self-consciousness, failure, and incapacity" which is manifested by the creation of a negative power exhibited by many students. It appears, upon reflection, that we are not just somewhere else besides Utopia, but that we are living in stark contrast to the utopian ideals outlined in Dewey's 1933 article-it appears, in fact, that we occupy a Dystopia, and thus our institution of schooling can be theorized as dystopian in nature and practice.

\section{Dewey's Aesthetics: A Rolling Stone Gathers No Moss}

Historically speaking, aesthetics has been largely preoccupied with the study of beauty, or what constitutes the beautiful; this, however, is not the definition of aesthetics we are concerned with here. Rather, we turn to the Greek adjective, aesthetikos, meaning "sensitive," and the Greek verb, aisthanomai, meaning to "perceive" or "to feel." The first philosopher to use the actual term "aesthetic" is Alexander Gottlieb Baumgarten. Baumgarten begins by positioning aesthetics as inferior to what he believes is the superior faculty of logic: "things known are to be known by the superior faculty as the object of logic; things perceived are to known by the inferior faculty, as the object of the science of perception, or aesthetic (emphasis in original)." ${ }^{15}$ More recently, Elliot Eisner theorizes the aesthetic in relation to its opposite, the anesthetic. For Eisner, the aesthetic "heightens feeling" and the anesthetic results in numbness. ${ }^{16}$ Generally speaking, aesthetics has been thought 
of as the study of a form of perception that is felt as a result of being engaged with an art object-in particular, beautiful objects.

Unfortunately, aesthetics centered on beauty does little to advance or reveal the power of Dystopia. Dystopian literature, in particular, offers little beauty, but rather offers totalizing systems of ugly oppression and dehumanization. Thus, we hope to theorize an aesthetic understanding of what might be experienced, or felt, with non-beautiful non-art objects. Dewey's Art as Experience radicalizes aesthetics-uproots it-and frees aesthetics from its attachment to art-objects, and repositions aesthetics in the realm of human perception with ordinary life and objects. In doing so, Dewey argues that all objects and activities of life might be considered for their aesthetic and anesthetic qualities.

Strangely, we want to recover Dewey's radical aesthetics by talking about what may seem the least radical of things on the earth: stones. If we pretend for a moment that our students are stones, objects that have experiences forced upon them by schools and educators, there is much to be learned from Dewey's theorizing about a stone. Dewey's Democracy and Education begins with the following passage:

I. Renewal of Life by Transmission.-The most notable distinction between living and inanimate beings is that the former maintain themselves by renewal. A stone when struck resists. If its resistance is greater than the force of the blow struck, it remains outwardly unchanged. Otherwise, it is shattered into smaller bits. Never does the stone attempt to react in such a way that it may maintain itself against the blow, much less so as to render the blow a contributing factor to its own continued action. While the living thing may easily be crushed by superior force, it none the less tries to turn the energies which act upon it into means of its own further existence. If it cannot do so, it does not just split into smaller pieces (at least in the higher forms of life), but loses its identity as a living thing (emphasis added). ${ }^{17}$

Our contention here is that Dewey's metaphor for the living and the un-living is also an apt metaphor for understanding what is at stake in the impossible duality that is the theme of our discussion: Utopia and Dystopia, or, more aptly, Utopian-turnedDystopian. In reaching for an impossible Utopia (100\% proficiency in reading and math, for example), we can do nothing other than smash our students, teachers, and administrators into smaller and smaller pieces: they lose their potential to grow; they lose their identities as living things; this utopian vision as perfection-rather than a messy "human" one-quickly turns into Dystopia.

On the other hand, if we were to imagine that Dewey's stone has that quality most essential to living beings, the natural inclination to turn what is acting upon it into energy toward its own renewal and further growth (essentially education in its broad sense), we can begin to see in relief the dangers entailed in a Utopia-turnedDystopia. The living, animated stone takes that which acts upon it and attempts to turn it into the "means of its own further existence"-it is educated, it grows, it 
is alive. In fact, Dewey's living stone seems to explain the very essence of human existence: we take what is enacted upon us, we learn from it, thereby turning such energy into furthering our own existence-again, we learn, we renew, we progress.

The Deweyan notion of the living stone is, we believe, also the basis for the utopian school described above, whose practices grow out of essential human traits, not out of nonliving, disconnected, inhumane objectives that lie outside of life itself. However, and as Dewey is clear to point out, though the living thing may continue to strive to turn that which acts upon it into a source for renewal, given a continual pounding, that life might very well be overwhelmed. Once overwhelmed, it becomes easy prey for controlling, splitting, fragmenting, and, ultimately, it loses its very identity as a living thing. This kind of dehumanization is, in fact, the essential theme of Dystopia around which its ancillary themes turn and is increasingly codified in educational policy and practice meant to accomplish the un-accomplishable: the educational perfection of human beings, even if it means eliminating everything human about them.

As to Dewey's rather profound discussion of aesthetics in Art as Experience, we want to direct our conversation towards his aesthetically radical notion that all of experience, not just those that happen in art museums or even in art as it is usually conceived (i.e., as the production or experiencing of "the beautiful"), might be seen for their aesthetic and educative qualities and, more importantly, to expose the miseducative and anesthetic qualities that demarcate Dystopia. As Dewey writes in Art as Experience, "any practical activity will, provided that it is integrated and moves by its own urge to fulfilment, have esthetic quality [emphasis added]." ${ }^{18}$ That is, "an experience," one that is aesthetic in nature and that entails growth and renewal, is indicative of those had by the living stone above; an experience, one with aesthetic qualities, is the hallmark of human existence; it is "educative." On this account, Dewey is clear to distinguish "an experience"-complete, purposeful, organic-from "experience"-fragmented, drifting, and scatterbrained; "experience" is "miseducative" in that it stops growth in its tracks- "miseducative" experiences dehumanize, splinter, and fragment. In short, "miseducative" experiences can be seen as dystopian in nature.

Returning to our student-as-stone metaphor, Dewey brings a stone to life in Art as Experience to aid in explaining his understanding of anesthetic and aesthetic qualities. He explains,

A generalized illustration may be had if we imagine a stone, which is rolling down hill, to have an experience. The activity is surely sufficiently 'practical.' The stone starts from somewhere, and moves, as consistently as conditions permit toward a place and state where it will be at rest-toward an end. Let us add, by imagination, to these external facts, the ideas that it looks forward with desire to the final outcome; that it is interested in the things it meets on its way, conditions that accelerate and retard its 
movement with respect to their bearing on the end; that it acts and feels toward them according to the hindering or helping function it attributes to them; and that the final coming to rest is related to all that went before as the culmination of a continuous movement. Then the stone would have an experience, and one with esthetic quality. ${ }^{19}$

As to experiences that are anesthetic, Dewey writes,

In much of experience we are not concerned with the connection of one incident with what went before and what comes after. There is no interest that controls attentive rejection or selection of what shall be organized into the developing experience. Things happen, but they are neither definitely included nor decisively excluded; we drift. We yield according to external pressure, or evade and compromise. There are beginnings and cessations, but no genuine initiations and concluding. One thing replaces another, but does not absorb it and carry it on. There is experience, but so slack and discursive that it is not an experience. Needless to say, such experiences are anesthetic. ${ }^{20}$

And, we would add, such anesthetic experiences are foundational to the construct we call Dystopia. To remind our readers, we utilize the metaphor of Dystopia because we feel that contemporary schooling offers not just disjointed experiences that lead students to "drift ... evade and compromise," but a totalizing experience that is often defined by fragmentation and dehumanization-experiences where the "final outcome" is void of student autonomy, identity, and voice.

\section{Dystopia as Anesthetic Experience}

With the above in mind, we want to suggest that Dewey's radical but essential contribution to aesthetic theory-his understanding that all of experience be seen for its aesthetic quality_can inform a broader dystopian lens through which to see our postmodern educational context. If we simply lay the dystopian themes we mention above next to, or maybe above, Dewey's delineation of traits of "experience" versus "an experience"; next to or above those qualities anesthetic and aesthetic, "educative" and "miseducative," we begin to see that contemporary (and advancing) dystopian policies and practices, those found in postmodern schooling as dictated by No Child Left Behind (NCLB), Race To The Top (RTT), Recognizing Educational Success, Professional Excellence and Collaborative Teaching (RESPECT), and Arnie Duncan's recent call for "Assessment 3.0," are direct, unrelenting manifestations of anesthetic, mis-educative, dystopian qualities. ${ }^{21}$ Dewey describes the drifting stone: inorganic, fragmented, purposeless, yielding, evading, compromising, "scatter-brained" and so forth. ${ }^{22}$ And, if we are to consider which of these various stones might be our children as they toil away in our contemporary schooling context, they certainly seem to be those who are continually put upon under the misguided utopian understanding that 
human beings can be pounded into a perfect educational existence-one that can be standardized and then measured for its achieved level of perfection - and one that is the direct opposite of that found in Dewey's utopians' understanding of education.

We would be remiss in noting that, certainly, as Dewey himself says, much of human experience is, in fact, drifting, disconnected, evasive, and compromising. Yet, and this is the crucial point, schooling in a democratic society sits at the center of our cultural and political heritage, and is the essential space wherein much of our identity is shaped and habituated. Schools have historically, rightly or wrongly, been seen as something of a socio-cultural panacea, and to a large extent the essential public institution for inculcating democratic habits of the heart and mind. Maybe a good portion of schooling has always been a bit "adrift." On the other hand, with the advent of Utopia-turned-Dystopia as a nationally prescribed set of policies, school experience has become deliberatively_by design — anesthetic, purposeless, and separated from the actual needs and desires of our students and their communities: in short, the schooling experience is in many ways dystopian; and, increasingly, schools are the breeding ground for the creation of a creeping Dystopia.

\section{The Matter of Love}

Before getting to some concluding thoughts, and as promised in our introductory comments, a brief word about the essential human emotion - that which is unique to human experience-and that which defends us against the slide into Dystopia of all kinds: love. In the quintessential $20^{\text {th }}$ century dystopian text, 1984 , Winston Smith is tortured into submission within the bowels of The Ministry of Love. Smith's torturer, O'Brien, is clear about the party's motives:

'The real power, the power we have to fight for night and day, is not power over things, but over men.' He paused, and for a moment assumed again his air of a schoolmaster questioning a promising pupil: "How does one man assert his power over another, Winston?"

Winston thought. "By making him suffer," he said.

"Exactly. By making him suffer. Obedience is not enough. Unless he is suffering, how can you be sure that he is obeying your will and not his own? Power is in inflicting pain and humiliation. Power is in tearing human minds to pieces and putting them together again in new shapes of your own choosing. So you begin to see, then, what kind of world we are creating? It is the exact opposite of the stupid hedonistic Utopias that the old reformers imagined. A world of fear and treachery and torment, a world of trampling and being trampled upon, a world which will grow not less but more merciless as it refines itself. Progress in our world will be progress toward more pain. The old civilizations claimed that they were founded on love and justice. Ours is founded upon hatred." ${ }^{23}$ 
We suspect that if we were to ask educational policy makers and those who uncritically follow those policies if they "love" their students they might say "yes," and claim that they are acting in those ways described earlier in our discussion for their students' own well-being--to save them from themselves. This, it seems, is what constitutes dystopian love: pounding "the other" into fragments to save them from themselves. ${ }^{24}$

To help us describe what we mean by dystopian love we turn to Erich Fromm, who describes the symbiotic relationship between masochistic and sadistic love. Masochistic love is the kind where one "gives up one's self, one's initiative and integrity;" sadistic love, the kind found in O'Brien's torture of Winston, "springs from the desire to swallow its object to make him a will-less instrument in one's own hand." Fromm likens these types of love to "expressions of one basic need which springs from a basic inability to be independent"; whereas the true form of love is premised on "strength, independence, integrity of the self, which can stand alone and bear solitude." ${ }^{25}$ Of course love of this type is often associated with achieving adulthood, but the seeds of one's inability to achieve this are born out of childhood experiences, those which are rampant in a dystopian context of schooling. Fromm continues,

Whether the domination is overtly authoritarian or subtly 'modern' makes no essential difference. In either case, it tends to undermine the strength of the self of the child and leads in later years to the development in him of the very same symbiotic [masochistic and sadistic] tendencies ... a continuous struggle for dominance and submission being conceived as love. ${ }^{26}$

There is a fine line between love and hate here. Thus, we claim the antidote to Dystopia is in the achievement of Fromm's conception of love. Only in the achievement of independent selves able to inculcate freedom in others, those who are able to ward off the human propensity for domination and control, can schools become less dystopian and otherwise humanely free.

The issue of love, particularly its nature relative to the human conditiona nature that takes that which is enacted upon it and, we hope, grows from it-is one that we believe can be addressed via a critical dystopian lens. This dystopian theoretical lens is essentially informed by an understanding of Dewey's radical aesthetics-a lens that can allow us to see the distinction between dystopian love and truly human love... if only we are brave enough first to look closely and critically at what we have created.

\section{Concluding Thoughts}

The dystopian theoretical perspective we suggest here, like many theories, can help us see what we can't from within more traditionally defined critical perspectives-critical perspectives that have distracted us from the broad institutional 
dystopian impact school policy mandates increasingly inflict on our youngest and most vulnerable citizens. Critical discourse, of late, dwells incessantly on a stubborn Marxist economic critique and identity politics, and we believe these discussions miss the universal nature of contemporary policy mandates and their almost universal destruction of selves (urban and suburban, rich and poor, minority and non-minority). The dehumanizing, covert dystopian violence goes well beyond urban schools in impoverished neighborhoods. Instead, it is increasingly universal, increasingly centralized, and goes increasingly unquestioned in its striving for a misguided academic Utopia. We believe that the prevailing critical theoretical perspectives and their proponents have been at best witnesses to the greatest baitand-switch in our brief educational history; and at worst, complicit in it: the bait was NCLB's promise to close the achievement gap, and the switch is ongoing as post-NCLB policy mandates increasingly focus on surveillance, control, and equating human development with grade-level data points. If we look closely, through a dystopian lens, we will see that the problems go much deeper than simply the over-utilization of standardized tests and the permanence of the achievement gap.

In summary, we believe that in recovering the radical nature of Dewey's aesthetics, in seeing the aesthetically inclusive shift towards all of experience, in understanding his aesthetics essentially, and in pushing it to its logical limits, we can begin to see the impact that our contemporary schooling practice is having: a Utopia-turned-Dystopia. We also believe that from this theoretical perspective, and in first seeing the troubles before us, we might remember that attaining a Utopia is impossible, dehumanizing, and is itself the first step towards dystopia. Dewey himself says as much in Experience and Nature: "We long, amid a troubled world, for perfect being. We forget that what gives meaning to the notion of perfection is the events that create longing, and that apart from them, a 'perfect' world would mean just an unchanging brute existential thing" (emphasis added). ${ }^{27}$ We believe that a dystopian educational theory, as we have begun to outline it here, is an important trope for understanding our contemporary postmodern educational context, the "brute existential thing" it has become, in essentially valuable ways. Most importantly, a dystopian theory of education provides a lens that can aid in warding off our postmodern drift into Dystopia.

In the opening vignette of this paper, many readers may hope that the professor found a way to disrupt and influence change within the walls of the school described and the perspective of the administrators who were engaged on a weekly basis. Yet, no such intervention was forged-even the aptly educated and trained, philosophically-oriented, un-tenured teacher educator fell victim to fear, surveillance, and selfconsciousness in the asymmetrical power relationship deemed fixed "in-partnership" with a school district. Other than holding court over a few teachers who volunteered to answer undergraduate teacher candidate questions-one who boldly declared she almost quit yesterday and cries most nights-little was (or could be) achieved in such 
a setting except a space for students to feel the unnecessary forms of destruction in their midst. The difficulty in trying to transform such an environment was due to the common sense that its logic had achieved in the vast majority of those involved in the daily workings of the school. Dystopian logic seemed to have become a type of blinding elixir that only those on the outside, far removed from public schooling, could possibly see. Consequently, this is why we believe the somewhat exaggerated method of a dystopian theoretical perspective can pierce through common sense and uproot the tentacles of fear, oppression, surveillance, and dehumanization that are at the heart of many educational policy initiatives today.

\section{BiBLIOGRAPHY}

Aschenbrenner, Karl and William B. Holther, trans. Alexander Gottlieb Baumgarten: Reflections on Poetry. Berkeley, CA: University of California Press, 1954.

Carr, Jeremy, Dawn Fidrick, \& Cevin Soling. The War on Kids. Directed by Cevin Soling. Bronx, NY: Spectacle Films, 2009. DVD.

Dewey, John. Democracy and Education. New York: Free Press, 1916/1997.

- - - Experience and Nature. Mineola, NY: Dover, 1925/2000.

-_-. "Dewey Outlines Utopian Schools." New York Times (New York), April 23, 1933

- - - Art as Experience. New York: Perigree, 1934.

- - - Experience and Education. New York: Touchstone, 1938/1997.

Duncan, Arne. "Choosing the Right Battles: Remarks and Conversation."

Presentation, at the American Educational Research Association Annual Meeting, San Francisco, CA, April 27-May 1, 2013.

Eisner, Elliot. The Arts and the Creation of Mind. New Haven, CT: Yale University Press, 2002.

Ewing, Heidi, Jannat Gargi, \& Rachel Grady. Jesus Camp. Directed by Rachel Grady \& Heidi Ewing. New York, NY: Magnolia Films, 2006. DVD.

Freire, Paulo. Pedagogy of the Oppressed. London: Continuum, 1970.

Fromm, Erich. "Selfishness and Self-Love," Psychiatry: Journal for the Study of Interpersonal Process 2 (1939): 507-523.

Orwell, George. 1984. New York: Penguin, 1949/1977.

Sheffield, Eric C. "Dystopian Love Manifested in a Dystopian Aesthetic: Insights into Contemporary Educational Practice from A Clockwork Orange." In Dystopia and Education: Insights into Theory Policy and Practice in an Age of UtopiaGone-Wrong, edited by Jessica A. Heybach and Eric C. Sheffield. Charlotte, N.C.: Information Age Publishing, 2013, 139-160.

\section{NOTES}

1. Günther Anders, Die atomare Drohung: Radikale Überlegungen (Munich: Beck,1981), 96, quoted in Geoffrey Winthrop-Young, "Hardware/Software/Wetware" in Critical Terms of Media Studies, eds. WJT Mitchell \& Mark B. N. Hanson, 193. 
2. John Dewey, Experience and Education (New York: Touchstone, 1938/1997); Jeremy Carr, Dawn Fidrick, \& Cevin Soling, The War on Kids, Directed by Cevin Soling (Bronx, NY: Spectacle Films, 2009). DVD.

3. Heidi Ewing, Jannat Gargi, \& Rachel Grady, Jesus Camp, Directed by Rachel Grady \& Heidi Ewing (New York: Magnolia Films, 2006). DVD.

4. John Dewey, "Dewey outlines utopian schools." New York Times (New York), April 23, 1933.

5. Ibid.

6. Ibid.

7. Ibid.

8. For more information on the Common Core Standards: http://www.corestandards. org/; edTPA: http://edtpa. aacte.org/welcome.

9. Dewey, "Utopia."

10. Dewey, "Utopia."

11. Ibid.

12. Ibid.

13. Paulo Freire, Pedagogy of the Oppressed (London: Continuum, 1970).

14. Dewey, "Utopia."

15. Karl Aschenbrenner and William B. Holther, trans., Alexander Gottlieb Baumgarten: Reflections on Poetry (Berkeley, CA: University of California Press, 1954), 4.

16. Elliot Eisner, The Arts and the Creation of Mind (New Haven, CT: Yale University Press, 2002), 81.

17. John Dewey, Democracy and Education (New York, NY: Free Press, 1916/1997), 4.

18. John Dewey, Art as Experience (New York, NY: Perigree, 1934), 41.

19. Ibid., 46.

20. Ibid., 39-40.

21. Arne Duncan, "Choosing the Right Battles: Remarks and Conversation" (presentation, American Educational Research Association Annual Meeting, San Francisco, CA, April 27-May 1, 2013).

22. Dewey's extended description of mis-educative experiences is as follows: “... experiences may be so disconnected from one another that, while each is agreeable or even exciting in itself, they are not linked cumulatively to one another. Energy is then dissipated and a person becomes scatter-brained. Each experience may be lively, vivid, and "interesting," and yet their disconnectedness may artificially generate dispersive, disintegrated, centrifugal habits. The consequence of formation of such habits is inability to control future experiences. John Dewey, Experience and Education (New York, NY: Touchstone, 1938/1997), 14.

23. George Orwell, 1984 (New York, NY: Penguin, 1949/1977), 266-67.

24. For a complete discussion of the aesthetic nature of dystopian love, see Eric C. Sheffield, "Dystopian Love Manifested in a Dystopian Aesthetic: Insights into Contemporary Educational Practice from A Clockwork Orange" in Jessica A. Heybach \& Eric C. Sheffield, eds., Dystopia and Education: Insights into Theory Policy and Practice in an Age of UtopiaGone-Wrong (Charlotte, N.C.: Information Age Publishing, 2013).

25. Fromm, Erich. "Selfishness and Self-Love," Psychiatry: Journal for the Study of Interpersonal Process 2 (1939): 514-15.

26. Ibid., 515.

27. John Dewey, Experience and Nature (Mineola, NY: Dover Publications, 1925/2000), 58. 
94 Jessica A. Heybach and Eric C. Sheffield

Jessica A. Heybach is assistant professor of Education at Aurora University; Aurora, Illinois.

Email: jvivirit@aurora.edu

Eric C. Sheffield is professor in the Reading, Foundations, and Technology Department at Missouri State University, Springfield.

Email: ericsheffield@missouristate.edu 